\title{
Traditional food and herbal uses of wild plants in the ancient South-Slavic diaspora of Mundimitar/ Montemitro (Southern Italy)
}

\author{
Alessandro di Tizio ${ }^{1}$, Łukasz Jakub Łuczaj², Cassandra L Quave ${ }^{3}$, Sulejman Redžić ${ }^{4}$ and Andrea Pieroni ${ }^{*}$
}

\begin{abstract}
Background: In Europe, only a limited number of cross-cultural comparative field studies or meta-analyses have been focused on the dynamics through which folk plant knowledge changes over space and time, while a few studies have contributed to the understanding of how plant uses change among newcomers. Nevertheless, ethnic minority groups and/or linguistic "isles" in Southern and Eastern Europe may provide wonderful arenas for understanding the various factors that influence changes in plant uses.
\end{abstract}

Methods: A field ethnobotanical study was carried out in Mundimitar (Montemitro in Italian), a village of approx. 450 inhabitants, located in the Molise region of South-Eastern Italy. Mundimitar is a South-Slavic community, composed of the descendants of people who migrated to the area during the first half of the $14^{\text {th }}$ century, probably from the lower Neretva valley (Dalmatia and Herzegovina regions). Eighteen key informants (average age: 63.7) were selected using the snowball sampling technique and participated in in-depth interviews regarding their Traditional Knowledge (TK) of the local flora.

Results: Although TK on wild plants is eroded in Montemitro among the youngest generations, fifty-seven taxa (including two cultivated species, which were included due to their unusual uses) were quoted by the study participants. Half of the taxa have correspondence in the Croatian and Herzegovinian folk botanical nomenclature, and the other half with South-Italian folk plant names. A remarkable link to the wild vegetable uses recorded in Dalmatia is evident. A comparison of the collected data with the previous ethnobotanical data of the Molise region and of the entire Italian Peninsula pointed out a few uses that have not been recorded in Italy thus far: the culinary use of boiled black bryony (Tamus communis) shoots in sauces and also on pasta; the use of squirting cucumber (Ecballium elaterium) juice for treating malaria in humans; the aerial parts of the elderberry tree (Sambucus nigra) for treating erysipelas in pigs; the aerial parts of pellitory (Parietaria judaica) in decoctions for treating haemorrhoids.

Conclusions: The fact that half of the most salient species documented in our case study - widely available both in Molise and in Dalmatia and Herzegovina - retain a Slavic name could indicate that they may have also been used in Dalmatia and Herzegovina before the migration took place. However, given the occurrence of several South-Italian plant names and uses, also a remarkable acculturation process affected the Slavic community of Montemitro during these last centuries. Future directions of research should try to simultaneously compare current ethnobotanical knowledge of both migrated communities and their counterparts in the areas of origin.

Keywords: Ethnobotany, Wild food plants, Montemitro, Molise-Slavic, Molise

\footnotetext{
* Correspondence: a.pieroni@unisg.it

${ }^{1}$ University of Gastronomic Sciences, Piazza Vittorio Emanuele 9, I-12060

Pollenzo Cuneo, Italy

Full list of author information is available at the end of the article
} 


\section{Introduction}

One of the most intriguing scientific questions in ethnobiology concerns the ways through which folk plant knowledge changes over space and time. In Europe, only a limited number of cross-cultural comparative field studies or meta-analyses of historical ethnobotanical literature focused on such dynamics so far [1-8], while an increasing number of studies have contributed to the understanding of how plant uses change among "newcomers" [9-17].

Ancient linguistic diasporas have instead been the focus of several field ethnobotanical surveys in Italy during the last decades. Studies on Traditional Knowledge (TK) of plant uses have thus far involved a number of ethnic minority groups within the Italian geographical region: in Northern Italy, Occitans (Provençal) [18-23], Franco-Provençal [20,24-26] and German Walser [27-29] groups in Piedmont, Ladins [30-33], Mócheno [34] and Cimbrian [35,36] Bavarians in Veneto and Trentino; Istro-Romanians in the Croatian Istria [37]; in Southern Italy: Albanian Arbëreshë in Lucania [38-40] and Greeks in Calabria [41,42]; in Sardinia, Tabarkins (Ligurians) [43].

The present study focused on the food and herbal ethnobotany of an ancient South-Slavic diaspora living in the village of Mundimitar/Montemitro, Molise Region, South-Eastern Italy.

The aims of this study were:

- to record folk food and herbal uses of wild plants and mushrooms in Mundimitar;

- to compare the collected ethnolinguistic data with those of Molise, surrounding Italian regions and of Croatia and Herzegovina;

- to compare the recorded ethnobotanical uses with all Italian ethnobotanical literature;

- to assess the resilience and cultural adaptations of the Slavic diaspora in perceptions (naming) and uses of wild plants.

\section{Methodology}

\section{Study site}

Mundimitar (in Italian Muntemitro) is a small village located at 508 m.a.s.l. in the Province of Campobasso, Molise Region, Southern Italy (Figure 1).

Like Acquaviva Collecroce and San Felice del Molise, Montemitro is the home to a Slavic community that migrated in the area, probably from the lower Neretva valley (Dalmatia and Herzegovina regions) during the first half of the $14^{\text {th }}$ century [44].

The village had a population of ca. 1,000 inhabitants until the 1970's when many locals migrated to Northern Italy or abroad for employment. Nowadays, the village is composed of ca. 450 inhabitants who speak a Western Štokavian dialect (na-našo in the local language, meaning "in our language"), known by linguists as Molise Slavic or Molise Croatian.

\section{Field study}

The field ethnobiological study was carried out in Mundimitar during several visits in 2009 and 2010. Eighteen key informants (average age: 63.7) were selected using snowball sampling techniques and participated in indepth interviews regarding their TK of the local flora. The focus of the interviews was on folk food and medicinal uses of wild food plants and mushrooms. Prior informed consent (PIC) was obtained verbally before commencing each interview and the guidelines of the AISEA (Italian Association for Ethno-Anthropological Sciences) [45] were adhered to.

Free-listing and semi-structured interview techniques were used. When available, the wild plant species cited during interviews were collected, verified by our interviewees, identified according to Pignatti's Flora d'Italia [46], named according to Tutin et al.'s Flora Europaea [47] and later deposited at the Herbarium of the University of Gastronomic Sciences in Pollenzo. Plant

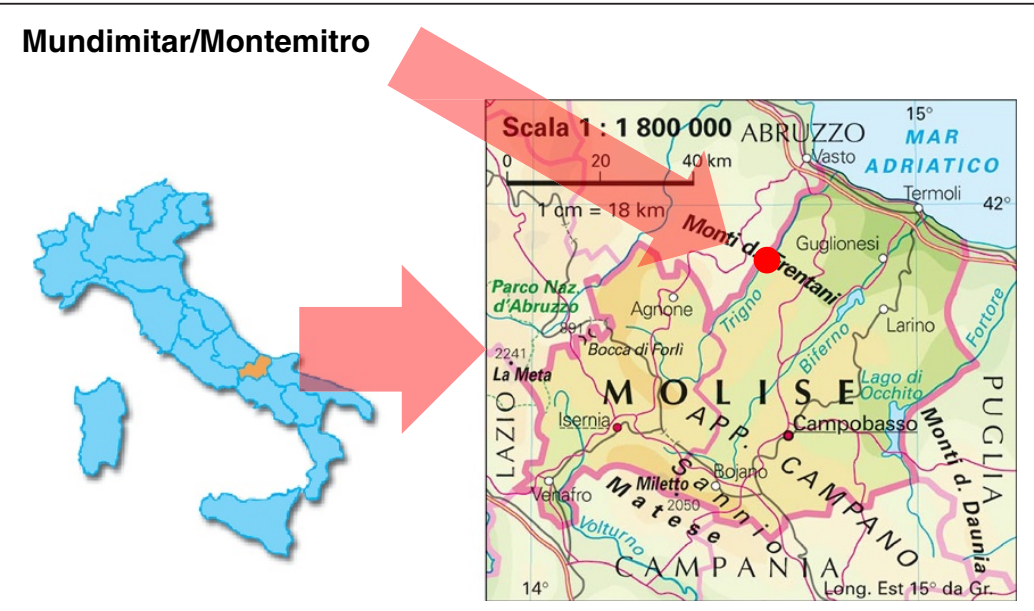

Figure 1 Location of Mundimitar/Montemitro. 
Table 1 Traditional food and medicinal uses of wild plants and mushrooms in Mundimitar/Montemitro

\begin{tabular}{|c|c|c|c|c|c|}
\hline Botanical taxon and family & $\begin{array}{l}\text { Local name(s) } \\
\text { in Mundimitar }\end{array}$ & $\begin{array}{l}\text { English } \\
\text { name }\end{array}$ & $\begin{array}{l}\text { Part(s) } \\
\text { used }\end{array}$ & $\begin{array}{l}\text { Folk use(s) in } \\
\text { Mundimitar }\end{array}$ & $\begin{array}{l}\text { Frequency } \\
\text { of citation }\end{array}$ \\
\hline $\begin{array}{l}\text { Allium sativum } \\
\text { L. (Amaryllidaceae) } \\
\text { (CULTIVATED) }\end{array}$ & Luk & Garlic & $\begin{array}{l}\text { Flowering } \\
\text { shoots }\end{array}$ & $\begin{array}{l}\text { Boiled, then preserved } \\
\text { in olive oil or vinegar; } \\
\text { in tomato sauces }\end{array}$ & +++ \\
\hline $\begin{array}{l}\text { Amaranthus retroflexus } \\
\text { L. (Amaranthaceae) }\end{array}$ & Pjedruš & Amaranth & Leaves & Raw in salads, or boiled & +++ \\
\hline $\begin{array}{l}\text { Apium nodiflorum (L.) } \\
\text { Lag. (Apiaceae) }\end{array}$ & Kanijola & $\begin{array}{l}\text { Fool's } \\
\text { water-cress }\end{array}$ & Aerial parts & $\begin{array}{l}\text { Raw in salads or between } \\
\text { two slices of bread }\end{array}$ & +++ \\
\hline $\begin{array}{l}\text { Armillaria mellea (Vahl) } \\
\text { P. Kumm and related } \\
\text { species (Marasmiaceae) }\end{array}$ & Rekkie mušil & $\begin{array}{l}\text { Honey } \\
\text { fungus }\end{array}$ & $\begin{array}{l}\text { Fruiting } \\
\text { body }\end{array}$ & Blanched, then fried & + \\
\hline $\begin{array}{l}\text { Asparagus acutifolius } \\
\text { L. (Asparagaceae) }\end{array}$ & Sparuga & $\begin{array}{l}\text { Wild } \\
\text { asparagus }\end{array}$ & Shoots & $\begin{array}{l}\text { Boiled, then fried in } \\
\text { omelets }\end{array}$ & +++ \\
\hline $\begin{array}{l}\text { Beta vulgaris subsp. } \\
\text { maritima (L.) Arcang. } \\
\text { (Amaranthaceae) }\end{array}$ & Blitva & Wild beet & Leaves & Boiled, then fried & +++ \\
\hline \multirow{2}{*}{$\begin{array}{l}\text { Borago officinalis } \\
\text { L. (Boraginaceae) }\end{array}$} & \multirow[t]{2}{*}{ Bureina } & \multirow[t]{2}{*}{ Borage } & \multirow[t]{2}{*}{ Young leale } & Boiled. & \multirow[t]{2}{*}{+++} \\
\hline & & & & $\begin{array}{l}\text { Coated with bread } \\
\text { crumbs, then deep fried }\end{array}$ & \\
\hline $\begin{array}{l}\text { Bunias erucago } \\
\text { L. (Brassicaceae) (?) }\end{array}$ & Rapanača & $\begin{array}{l}\text { Crested warty } \\
\text { cabbage }\end{array}$ & Whorls & Boiled and fried & + \\
\hline $\begin{array}{l}\text { Calendula arvensis } \\
\text { L. (Asteraceae) }\end{array}$ & Kalendula & Marigold & Flowers & In salads & + \\
\hline $\begin{array}{l}\text { Cantharellus cibarius } \\
\text { Fr. (Cantharellaceae) }\end{array}$ & Galuč & Chanterelle & Fruiting body & Blanched, then fried & + \\
\hline $\begin{array}{l}\text { Centaurium erythraea } \\
\text { Rafn. (Gentianaceae) }\end{array}$ & Džencjanela & Centaury & Aerial parts & Decoction as a panacea & + \\
\hline $\begin{array}{l}\text { Cichorium intybus } \\
\text { L. (Asteraceae) }\end{array}$ & Čikoria & Wild cichory & Whorls & $\begin{array}{l}\text { Boiled, then fried in olive } \\
\text { oil with garlic }\end{array}$ & ++ \\
\hline Clavaria sp. (Clavariaceae) & Picele & Coral fungus & Fruiting body & Boiled, then fried & + \\
\hline \multirow[t]{2}{*}{$\begin{array}{l}\text { Clematis vitalba } \\
\text { L. (Ranunculaceae) }\end{array}$} & \multirow[t]{2}{*}{ Škrabut } & \multirow[t]{2}{*}{ Traveller's joy } & \multirow[t]{2}{*}{ Shoots } & $\begin{array}{l}\text { Boiled, then fried or in } \\
\text { sauces; digestive aid }\end{array}$ & \multirow[t]{2}{*}{+++} \\
\hline & & & & $\begin{array}{l}\text { Stems are directly applied } \\
\text { on the tooth to treat } \\
\text { toothache }\end{array}$ & \\
\hline Cornus mas L. (Cornaceae) & Kurnja & $\begin{array}{l}\text { Cornel cherry } \\
\text { tree }\end{array}$ & Fruits (Kurnjal) & $\begin{array}{l}\text { Consumed raw, or } \\
\text { dried/smoked; liqueurs }\end{array}$ & +++ \\
\hline \multirow{2}{*}{$\begin{array}{l}\text { Crataegus. monogyna } \\
\text { Jacq. and C. oxyacantha } \\
\text { L. (Rosaceae) }\end{array}$} & \multirow[t]{2}{*}{ Glog } & \multirow[t]{2}{*}{ Hawthorn } & \multirow[t]{2}{*}{ Fruits (Glogbili) } & Consumed raw as snack. & \multirow[t]{2}{*}{+++} \\
\hline & & & & $\begin{array}{l}\text { The thorny stems were } \\
\text { used to insert into figs } \\
\text { for drying. }\end{array}$ & \\
\hline \multirow[t]{2}{*}{$\begin{array}{l}\text { Cydonia oblonga } \\
\text { Mill. (Rosaceae) }\end{array}$} & \multirow[t]{2}{*}{ Kutunja } & \multirow[t]{2}{*}{ Quince } & \multirow[t]{2}{*}{ Fruits } & $\begin{array}{l}\text { Boiled with wine, for } \\
\text { treating sore throats. }\end{array}$ & \multirow[t]{2}{*}{+++} \\
\hline & & & & Jam. & \\
\hline $\begin{array}{l}\text { Cynara cardunculus } \\
\text { L. (Asteraceae) }\end{array}$ & Ošnak & $\begin{array}{l}\text { Wild artichocke } \\
\text { or wild cardoon }\end{array}$ & Stems & $\begin{array}{l}\text { Boiled, then fried } \\
\text { with eggs }\end{array}$ & +++ \\
\hline $\begin{array}{l}\text { Cynodon dactylon (L.) } \\
\text { Pers. (Poaceae) }\end{array}$ & Gramača & Bermuda grass & Whole plant & Decoction as a diuretic & ++ \\
\hline $\begin{array}{l}\text { Diplotaxis erucoides (L.) } \\
\text { DC. (Brassicaceae) }\end{array}$ & Marijun & White wall-rocket & Leaves & $\begin{array}{l}\text { Raw in salads, more } \\
\text { often fried in the pan }\end{array}$ & +++ \\
\hline $\begin{array}{l}\text { Ecballium elaterium (L.) } \\
\text { A. Rich. (Cucurbitaceae) }\end{array}$ & Tikvica divlja & $\begin{array}{l}\text { Squirting } \\
\text { cucumber }\end{array}$ & Fruit juice & $\begin{array}{l}\text { Instilled in the nose for } \\
\text { treating malaria or spread } \\
\text { on women breast for } \\
\text { weaning babies }\end{array}$ & ++ \\
\hline
\end{tabular}


Table 1 Traditional food and medicinal uses of wild plants and mushrooms in Mundimitar/Montemitro (Continued)

\begin{tabular}{|c|c|c|c|c|c|}
\hline $\begin{array}{l}\text { Eruca sativa Miller } \\
\text { (Brassicaceae) }\end{array}$ & Rucola & Rocket & Leaves & Raw in salads & +++ \\
\hline $\begin{array}{l}\text { Eryngium campestre } \\
\text { L. (Apiaceae) (?) }\end{array}$ & Sikavac & Field eryngo & Leaves & $\begin{array}{l}\text { Decoction for treating } \\
\text { eye inflammations }\end{array}$ & + \\
\hline Ficus carica L. (Moraceae) & Smokva & Fig tree & Pseudofruits & Eaten fresh or dried & +++ \\
\hline $\begin{array}{l}\text { Foeniculum vulgare Mill. } \\
\text { subsp. piperitum (Ucria) } \\
\text { Cout. (Apiaceae) }\end{array}$ & Finoč & Wild fennel & Fruits & $\begin{array}{l}\text { Seasoning for home-made } \\
\text { sausages; decoctions as } \\
\text { diuretic or for treating } \\
\text { gastric reflux }\end{array}$ & +++ \\
\hline \multirow{2}{*}{$\begin{array}{l}\text { Glycyrrhiza glabra } \\
\text { L. (Fabaceae) }\end{array}$} & \multirow[t]{2}{*}{ Gurgulica } & \multirow[t]{2}{*}{ Licorice } & \multirow[t]{2}{*}{ Root } & Consumed raw as snack. & \multirow[t]{2}{*}{+++} \\
\hline & & & & $\begin{array}{l}\text { The aerial parts used as } \\
\text { insect repellent. }\end{array}$ & \\
\hline $\begin{array}{l}\text { Humulus lupulus } \\
\text { L. (Cannabaceae) }\end{array}$ & Lupare & Wild hop & Shoots & Boiled, then fried in omelet & ++ \\
\hline $\begin{array}{l}\text { Hydnum repandum } \\
\text { L.: Fr. (Hydnaceae) }\end{array}$ & Lengaove & $\begin{array}{l}\text { Wood } \\
\text { hedgehog }\end{array}$ & Fruiting body & Blanched, then fried & ++ \\
\hline \multirow{2}{*}{$\begin{array}{l}\text { Lupinus albus L. spp. } \\
\text { (Fabaceae) (CULTIVATED) }\end{array}$} & \multirow[t]{2}{*}{ Lupino } & \multirow[t]{2}{*}{ Lupin } & \multirow{2}{*}{$\begin{array}{l}\text { Flower shoots } \\
\text { Aerial parts }\end{array}$} & Boiled, then fried. & \multirow[t]{2}{*}{+} \\
\hline & & & & $\begin{array}{l}\text { The decoction of the whole } \\
\text { aerial parts is used in external } \\
\text { washes for treating pig } \\
\text { erysipelas }\end{array}$ & \\
\hline $\begin{array}{l}\text { Malva sylvestris } \\
\text { L. (Malvaceae) }\end{array}$ & Slis & Mallow & $\begin{array}{l}\text { Leaves and } \\
\text { flowers }\end{array}$ & $\begin{array}{l}\text { Decoction for treating } \\
\text { digestive troubles, bronchitis, } \\
\text { or as a laxative for children }\end{array}$ & +++ \\
\hline $\begin{array}{l}\text { Matricaria chamomilla } \\
\text { L. (Asteraceae) }\end{array}$ & Kamomilla & Chamomile & $\begin{array}{l}\text { Flowering tops } \\
\text { or stems }\end{array}$ & $\begin{array}{l}\text { Decoction, as a mild } \\
\text { tranquillizer }\end{array}$ & ++ \\
\hline $\begin{array}{l}\text { Mercurialis annua } \\
\text { L. (Euphorbiaceae) }\end{array}$ & Merkulela & Mercurya & Leaves & $\begin{array}{l}\text { Boiled in soups (mixed with } \\
\text { other herbs), or in purgative } \\
\text { decoctions }\end{array}$ & ++ \\
\hline $\begin{array}{l}\text { Olea europaea L. var. } \\
\text { sylvestris Brot. (Oleaceae) }\end{array}$ & Maslina & Wild olive tree & Branches & Used for drying figs & ++ \\
\hline $\begin{array}{l}\text { Origanum vulgare } \\
\text { L. (Lamiaceae) }\end{array}$ & Pljei & Wild oregano & Flowering tops & Seasoning & +++ \\
\hline $\begin{array}{l}\text { Papaver rhoeas } \\
\text { L. (Papaveraceae) }\end{array}$ & Mak & Corn poppy & $\begin{array}{l}\text { Young aerial } \\
\text { parts }\end{array}$ & Raw in salads, or cooked & +++ \\
\hline \multirow[t]{2}{*}{$\begin{array}{l}\text { Parietaria judaica } \\
\text { L. (Urticaceae) }\end{array}$} & \multirow[t]{2}{*}{ Kolana } & \multirow[t]{2}{*}{ Pellitory } & \multirow[t]{2}{*}{ Aerial parts } & $\begin{array}{l}\text { Decoction in external use } \\
\text { for treating hemorrhoids } \\
\text { (affected parts exposed } \\
\text { to vapors). }\end{array}$ & \multirow[t]{2}{*}{++} \\
\hline & & & & Necklaces for children & \\
\hline \multirow{2}{*}{$\begin{array}{l}\text { Picris echioides L. and } \\
\text { P. hieracioides L. (Asteraceae) }\end{array}$} & \multirow[t]{2}{*}{ Tustača } & \multirow[t]{2}{*}{ Oxtongue } & \multirow{2}{*}{$\begin{array}{l}\text { Whorls and } \\
\text { shoots }\end{array}$} & Shoots eaten raw as snack. & \multirow[t]{2}{*}{++} \\
\hline & & & & Whorls boiled and fried. & \\
\hline $\begin{array}{l}\text { Portulaca oleracea } \\
\text { L. (Portulacaceae) }\end{array}$ & Prkatj & Purslane & Aerial parts & Raw in salads & ++ \\
\hline Prunus spinosa L. (Rosaceae) & Ndrnjela & Sloe & Fruits & $\begin{array}{l}\text { Gathered an consumed } \\
\text { after the frost; liqueurs }\end{array}$ & ++ \\
\hline $\begin{array}{l}\text { Punica granatum } \\
\text { L. (Punicaceae) }\end{array}$ & Šipak & Pomegranate & Fruits & Consumed raw in winter & ++ \\
\hline $\begin{array}{l}\text { Pyrus pyraster Burgsd. } \\
\text { (Rosaceae) }\end{array}$ & Trnovača & Wild pear tree & Fruits & $\begin{array}{l}\text { Gathered and consumed } \\
\text { after the frost }\end{array}$ & ++ \\
\hline $\begin{array}{l}\text { Quercus virgiliana (Ten.) } \\
\text { Ten. (Fagaceae) (?) }\end{array}$ & Sladul & Oak & Kernel & Consumed raw & + \\
\hline Rosa canina L. (Rosaceae) & Skorčavata & Dog rose & Pseudofruits & $\begin{array}{l}\text { Decoction for treating } \\
\text { sore throat (sometimes } \\
\text { together wild dried figs, } \\
\text { apple slices, and barley) }\end{array}$ & +++ \\
\hline
\end{tabular}


Table 1 Traditional food and medicinal uses of wild plants and mushrooms in Mundimitar/Montemitro (Continued)

\section{Ruscus aculeatus}

L. (Asparagaceae)

Ruta graveolens

L. (Rutaceae)

\section{Leprencia}

Ruta

Salvia verbenaca
L. (Lamiaceae)
Sambucus nigra
L. (Caprifoliacea

Sinapis alba $\mathrm{L}$ and

S. arvensis L. (Brassicaceae)

Sonchus arvensis L. and

S. oleraceus L. (Asteraceae)

Sorbus domestica

L. (Rosaceae)

Stellaria media (L.) Vill.

(Caryophyllaceae)

Tamus communis

L. (Dioscoreaceae)

Teucrium chamaedrys

L. (Lamiaceae)

Umbilicus rupestris (Salisb.)

Dandy (Crassulaceae)

Urtica dioica L (Urticaceae)
Prsenica Meadow sage Leaves

Baz

Sinapa

Kostriš/Kašgn

Wild mustard

Sow thistle

Oskoruša

Mišakina

Service tree

Chickweed

Gljuštre

Kametr

Kopič

Kopriva

Džurdžula shoots
Shoots

Aerial parts

Aerial parts and fruits
Boiled, then fried.

Dried branches were used to clean the fireplace

Aromatizing grappa.

Kept under the pillow for treating worms in children.

A few leaves eaten raw by pregnant women to prevent miscarriage (in the past)

Applied externally with pork fat as a suppurative or for treating insect stings

Decoction, then in external washes for treating erysipelas in pigs.

Fruits juice used as ink in the past.

Raw in salads, more often cooked in the pan

Boiled, then fried in the pan or cooked in tomato sauce

Consumed after natural fermentation

Fodder for hens

Boiled, then fried in the pan with eggs or tomato sauce (sometimes served on noodles)

Decoction for treating malaria (in the past) and hypertension

Crushed and mixed with pork fat and soot for treating furuncles

Boiled, then mixed with ricotta cheese, in filled pasta.

Leaves and

Decoction in external washes for strengthening the hair

Eaten after natural fermentation +

family names follow the recent classification (III) of the Angiosperm Phylogeny Group. The local folk plant names cited during interviews were recorded and transcribed in Serbo-Croatian (after the Yugoslav dissolved, also named BCSM - Bosnian/Bosniak-Croatian-SerbianMontenegrin).

\section{Data analysis}

The data collected during the field study were sorted in Microsoft ${ }^{\circledR}$ Excel.

Two in-depth comparisons were conducted:
- the former, concerning folk plant names, with the standard work on Croatian and Italian folk phytonimy $[48,49]$, a comprehensive review of the food ethnobotany of Abruzzo (the Italian region bordering Molise) [50], and unpublished ethnobotanical data of SR from Herzegovina as well as the unpublished list of wild food plants sold in the main eleven Dalmatian vegetable markets in March 2012 (ŁŁ);

- the latter, concerning the folk plant uses, with the most comprehensive review of the Italian ethnobotany (published in 2006) [51] and a few 


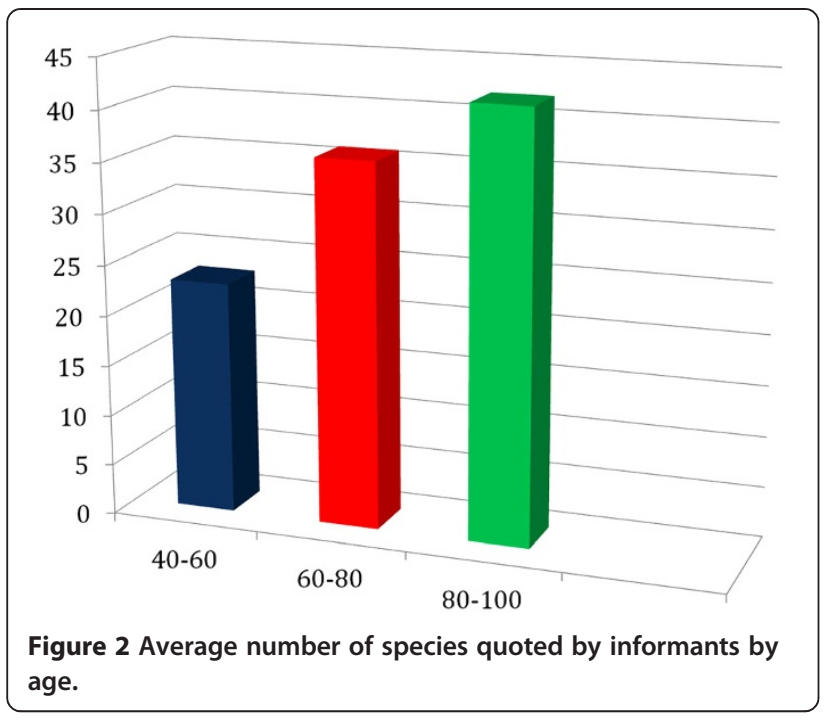

additional recent ethnobotanical field studies conducted in the Molise region [52-55]. Data from the studied village concerning wild green vegetables were compared with Croatian literature concerning plants use in Dalmatia [56-59] and with personal
(ŁŁ ) observations on wild vegetables sold in Dalmatian markets in 2012.

\section{Results and discussion}

Table 1 shows the local food and medicinal uses of wild vascular plants and mushrooms recorded in Montemitro. Fifty-seven species were identified by study participants. The table includes also the unusual food uses of two cultivated species (garlic and lupine). The limited number of identified fungi is attributed to the fact that most of the cited folk names did not occur during the visit in the field and could not be clearly identified.

Figure 2 shows that TK on wild plants is eroded in Montemitro among the youngest generations, thus confirming trends that are the similar throughout Southern Europe and in a large part of the world.

Table 2 shows the ethnolinguistic comparative analysis of the most quoted species during the free-listing exercise (quoted by more than $40 \%$ of the informants).

Half of the taxa have correspondence in the Croatian and Herzegovinian folk botanical nomenclature, and the other half with South-Italian folk plant names.

Table 2 Ethnolinguistic analysis of the most quoted wild food plants in Mundimitar/Montemitro (linguistic correspondences are underlined)

\begin{tabular}{|c|c|c|c|}
\hline Botanical taxon & $\begin{array}{l}\text { Local name (s) } \\
\text { in Mundimitar }\end{array}$ & $\begin{array}{l}\text { Folk name (s) in Croatia [48] and } \\
\text { Herzegovina (unpublished data) }\end{array}$ & $\begin{array}{l}\text { Folk name (s) in Molise and surrounding } \\
\text { South Italian regions }[49,50,52,59]\end{array}$ \\
\hline Amaranthus retroflexus & Pjedruš & Lodoba, Štir & Cime de halle, Pricacchione, $\underline{\text { Pederosse }}$ \\
\hline Apium nodiflorum & Kanijola & Celer & Candele, Cannizzole, Cannole, Lacce selvagge, Sellarina \\
\hline Asparagus acutifolius & Sparuga & Sparožin, Šparoga & Sparacane, Sparaci, Sparge, Sperne, Spinele \\
\hline Beta vulgaris & Blitva & Bitva divja, Blitva divja, Cikla & Biete, Biote \\
\hline Borago officinalis & Bureina & Borač, Boražina & Burracce, Burraina, Verraina \\
\hline Clematis vitalba & Škrabut & Pavina, Pavit, Škrobut & Vitavale, Vitelle, Vitacchie \\
\hline Cornus mas & Kurnja & Drijen, Drin & Corniale, Crugnare, Vrignale \\
\hline $\begin{array}{l}\text { Crataegus monogynal } \\
\text { C. oxyacantha }\end{array}$ & Glog & $\underline{\text { Glog }}$ & Arciprande, Bianghespine, Ciciarille, Spine bianghe \\
\hline Cynara cardunculus & Ošnak & Artičok, Gardun & Cardone, Carducce, Scalelle \\
\hline Foeniculum vulgare & Finoč & Komorač, Mirodjija, Morač & Fenucchie \\
\hline Mercurialis annua & Mrkulela & Resulja, Šcerenica & Mercorella, $\underline{\text { Murculella }}$ \\
\hline Origanum vulgare & Pljei & $\begin{array}{l}\text { Metvica, Mravinac, Vranilovka, } \\
\text { Vranilova trava }\end{array}$ & Arigano, Pnliejo, Regana \\
\hline Papaver rhoeas & Mak & Bologlav, Mak divlji & Papaina,Papambele, Pupille \\
\hline Portulaca oleracea & Prkatj & Štucliak, Tušani, Tušt & $\underline{\text { Perchiacche, Porcacchie, Precacchie }}$ \\
\hline Prunus spinosa & Ndrnjela & Brombuli, Crni trn, Trnjina & 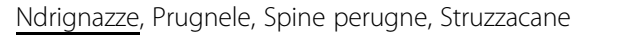 \\
\hline Rosa canina & Skorčavata & Srbiguz, Šipak, Šipurak, & Cacavescie, Raspacule, Scarciacule, Stracciacule \\
\hline Sinapis spp. & Sinapa & Gorušica, Muštarde & Lassane, Sinape \\
\hline Sonchus spp. & Kostriš/ Kašgn & 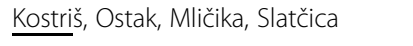 & Cascigne, Crespigne, Respigne \\
\hline Sorbus domestica & Oskoruša & Oskoruša & Ciorve, Scioreve \\
\hline Tamus communis & Gljuštre & $\underline{B l j u s ̌ t}$ & Afine, Curone, Defano \\
\hline Urtica dioica & Kopriva & Bažgava, Kopriva, Žara & Ardiche, Arteche, Strica \\
\hline
\end{tabular}


Table 3 Comparison of the use of wild green vegetables in Mundimitar with the studies from Dalmatia and Hercegovina (the areas where the diaspora of Mundimitar originated)

\begin{tabular}{|c|c|c|}
\hline & $\begin{array}{l}\text { Use in the } \\
\text { W Balkans }\end{array}$ & $\begin{array}{c}\text { Use in } \\
\text { Mundimitar }\end{array}$ \\
\hline Amaranthus retroflexus L. (Amaranthaceae) & G & $x$ \\
\hline Apium nodiflorum (L.) Lag. (Apiaceae) & & $x$ \\
\hline $\begin{array}{l}\text { Asparagus spp. (mainly } \\
\text { Asparagus acutifolius L. ) (Asparagaceae) }\end{array}$ & $B, G, C, M$ & $x$ \\
\hline Beta vulgaris L. (Amaranthaceae) & $B, G$ & $x$ \\
\hline Borago officinalis L. (Boraginaceae) & $G, S$ & $x$ \\
\hline Bunias erucago L. (Brassicaceae) & G & $x$ \\
\hline Cichorium intybus L. (Asteraceae) & $B, G, S$ & $x$ \\
\hline Clematis vitalba L. (Ranunculaceae) & G & $x$ \\
\hline Cynara cardunculus L. (Asteraceae) & & $x$ \\
\hline Diplotaxis erucoides (L.) DC. (Brassicaceae) & & $x$ \\
\hline Eruca sativa Miller (Brassicaceae) & $B, G$ & $x$ \\
\hline Humulus lupulus L. (Cannabaceae) & & $x$ \\
\hline Mercurialis annua L. (Euphorbiaceae) & & $x$ \\
\hline Papaver rhoeas L. (Papaveraceae) & $G, C, S, L$ & $x$ \\
\hline Picris echioides L. (Asteraceae) & $L$ & $x$ \\
\hline P. hieracioides L. (Asteraceae) & & $x$ \\
\hline Portulaca oleracea L. (Portulacaceae) & G & $x$ \\
\hline Ruscus spp. (Asparagaceae) & $B, G, C$ & $x$ \\
\hline Sinapis alba $\mathrm{L}$ and $\mathrm{S}$. arvensis $\mathrm{L}$. (Brassicaceae) & & $x$ \\
\hline Sonchus spp. (Asteraceae) & $B, G, C, S, L$ & $x$ \\
\hline Tamus communis L. (Dioscoreaceae) & $B, G, S, M$ & $x$ \\
\hline Urtica dioica L (Urticaceae) & S & $x$ \\
\hline Foeniculum vulgare Mill. (Apiaceae) & $B, G, C, S, L$ & $\begin{array}{l}\text { only fruits } \\
\text { as seasoning }\end{array}$ \\
\hline Allium ampeloprasum L. (Liliaceae) & $B, G, S, L$ & \\
\hline Anchusa arvensis (L.) M. Bieb. (Boraginaceae) & C & \\
\hline Anchusa sp. (Boraginaceae) & C & \\
\hline Arum italicum Mill. (Araceae) & B & \\
\hline Brassica oleracea L. (Brassicaceae) & G & \\
\hline Capsella bursa-pastoris L. (Brassicaceae) & G & \\
\hline Chenopodium urbicum L. (Chenopodiaceae) & B & \\
\hline Cirsium arvense L. (Asteraceae) & $B, G$ & \\
\hline Crepis sp. (Asteraceae) & $C, L$ & \\
\hline Crepis sancta (L.) Babc. (Asteraceae) & C & \\
\hline Crithmum maritimum L. (Apiaceae) & $B, G$ & \\
\hline Daucus carota L. (Apiaceae) & $B, G, S, L$ & \\
\hline $\begin{array}{l}\text { Diplotaxis tenuifolia (L.) DC. } \\
\text { (Brassicaceae) }\end{array}$ & $B, G$ & \\
\hline $\begin{array}{l}\text { Erodium cicutarium (L.) L'Hér. ex } \\
\text { Aiton (Geraniaceae) }\end{array}$ & C & \\
\hline $\begin{array}{l}\text { Eryngium maritimum L. and E. campestre } \\
\text { L. (Asteraceae) }\end{array}$ & $B, G$ & \\
\hline
\end{tabular}

Table 3 Comparison of the use of wild green vegetables in Mundimitar with the studies from Dalmatia and Hercegovina (the areas where the diaspora of Mundimitar originated) (Continued)

\begin{tabular}{|c|c|}
\hline & $\begin{array}{l}\text { Use in the Use in } \\
\text { W Balkans Mundimitar }\end{array}$ \\
\hline Geranium molle L. (Geraniaceae) & C \\
\hline Hirschfeldia incana (L.) Lagr.-Foss. (Brassicaceae) & G \\
\hline Hypochoeris radicata L. (Asteraceae) & G \\
\hline Lactuca perennis L. (Asteraceae) & $\mathrm{B}$ \\
\hline Lactuca serriola L. (Asteraceae) & S \\
\hline Leontodon tuberosus L. (Asteraceae) & $\mathrm{B}$ \\
\hline Mentha aquatica L. (Lamiaceae) & $\mathrm{B}$ \\
\hline Ornithogalum umbellatum L. (Liliaceae) & G \\
\hline Reichardia picroides (L.) Roth. (Asteraceae) & $\mathrm{G}, \mathrm{S}$ \\
\hline Ranunculus muricatus L. (Ranunculaceae) & C \\
\hline Rhagadiolus stellatus (L.) Gaertn. (Asteraceae) & C \\
\hline Rumex spp. (Polygonaceae) & $G, C$ \\
\hline Salicornia herbacea L. (Amaranthaceae) & G \\
\hline Silene latifolia Poir. (Caryophyllaceae) & $L$ \\
\hline Salvia verbenaca L. (Lamiaceae) & C \\
\hline $\begin{array}{l}\text { Silene vulgaris (Mch.) Garcke and related } \\
\text { species (Caryophyllaceae) }\end{array}$ & $B, G$ \\
\hline Smilax aspera L. (Smilacaceae) & G \\
\hline $\begin{array}{l}\text { Taraxacum megalorrhizon (Forssk.) } \\
\text { Hand.-Mazz. (Asteraceae) }\end{array}$ & B \\
\hline Taraxacum officinale Weber (Asteraceae) & $B, G, L$ \\
\hline Tordylium apulum L. (Apiaceae) & C \\
\hline Tragopogon pratensis L. (Asteraceae) & $B, G, S$ \\
\hline Urospermum picroides (L.) Desf. (Asteraceae) & $G, C, L$ \\
\hline Urtica pilulifera L. (Urticaceae) & $B, G$ \\
\hline
\end{tabular}

B - Bakić and Popović (in this study it is unclear if the data is about eating green parts or underground organs) [56], G - Grlić [57], C - Curčić [58], S- Sardelić [59], L - most commonly sold wild greens in Dalmatian markets in 2012 in the form of a vegetable mix (Łuczaj, unpublished); M - sold commonly in Dalmatian markets in 2012 as separate bunches (Łuczaj, unpublished).

The most quoted species still retain a Slavic name and may have also been used in Dalmatia and Herzegovina before the migration took place. A similar link between linguistic cognates and cultural salience has been shown in a recent food ethnobotanical study conducted among a Greek minority in Calabria [41]. However, this analysis may only express a reasonable probability of the original permanence of plant uses into a new environmental and cultural space, but it cannot be excluded that migrant groups may have acquired new practices of use of previously known plants from the autochthonous population, thus resulting in naming plants with the original language and using them in a very different way from the original one. 
On the other hand, the fact that in our case study half of the most salient species - widely available both in Molise and in Dalmatia and Herzegovina-- have SouthItalian folk names demonstrates a strong acculturation process that has affected the Slavic community of Montemitro during these last centuries.

We have also compared our findings with all of the previous ethnobotanical data of the Molise Region and of the entire Italian Peninsula. A few uses seem to have been recorded for the first time:

- the culinary use of boiled black bryony (Tamus communis) shoots in sauces and also with pasta;

- the use of squirting cucumber (Ecballium elaterium) juice for treating malaria in humans (in the past);

- the use of aerial parts of the elderberry tree (Sambucus nigra) for treating erysipelas in pigs;

- the use of decoctions of pellitory (Parietaria judaica) for treating haemorrhoids.

Specific ethnobotanical surveys conducted in Dalmatia and Herzegovina are missing in the literature, thus making it very difficult to draft a comprehensive comparison on plant uses. However, a food use of black bryony shoots, which is very common in Mundimitar, seems to be nowadays also common in the Istrian cuisine in Croatia [60] as well in Dalmatia, where it is commonly sold in markets ( $Ł E$ personal observation, 2012), while in Molise and Abruzzo its food use is considered obsolete.

The wild vegetable mix called mišanca (Zadar-Split)/ pazija (Dubrovnik), sold in every market of the Dalmatian coast (surveyed in March 2012, Łuczaj unpubl.) contains many of the plants used in the study area. For example Sonchus spp., Foeniculum vulgare, Papaver rhoeas, Picris echioides, and to a much lesser extent Eryngium sp. are used as food in Dalmatia nowadays (Table 3). However the existence of this concept of vegetable mix was not recorded in the study area. Strikingly, the data from the study area contain relatively few Asteraceae species, nowadays widely used in Dalmatia under the name radič or žutenica (e.g. Taraxacum spp., Crepis spp.) and a few other related genera). It must be kept in mind that Dalmatia was under a strong Greek, Roman and Venetian influence, and that the practice of using a variety of wild vegetables in Dalmatia may have a nonSlavic origin. Thus it may be that some of the uses brought by the Slavic emigrants to Italy are actually reimports of Venetian or Latin customs.

It is worth pointing out that nowadays in Dalmatia wild vegetables are mainly boiled, strained and seasoned with olive oil whereas the described uses in the study area often refer to frying, which may be reflective of a more recent acquisition of Italian cooking practices.
The food use of mercury (Mercurialis annua) leaves in soups has instead been recorded only one other time in Italy, in two studies conducted in North-Western Tuscany in the Lucca area [61,62].

\section{Conclusions}

This study demonstrates that even within ancient diasporas, as in the Slavic community of Mundimitar, which still exists in Italy after more than five centuries since it was founded, it is possible to find traces of resilience of original TK regarding plants.

A few uses of most quoted plants, which are still named in the original language, may have originated in the migrants' areas of origin (Dalmatia and Herzegovina).

However, TK is the result of dynamic processes and the case study that we have analysed here also demonstrates a high degree of adaptation, which is shown in both the folk botanical nomenclature (half of the most quoted botanical taxa are named in South-Italian) and in the actual plant folk uses too (very few uses do not correspond with the Italian ethnobotany).

These considerations show that, in contrast with analogous studies conducted on the ethnobotany of recent migrants/newcomer' groups, TK about plants within ancient diasporas is a very complex, and not well understood, phenomenon.

\section{Competing interests \\ The authors declare that they have no competing interests.}

\section{Authors' contributions}

AdT and AP conceived the study and conducted the field study; AP, ŁŁ, SR, and CLQ performed the data analysis and drafted the discussion. All authors read and approved the final manuscript.

\section{Acknowledgements}

Special thanks are due to all the inhabitants of Mundimitar/Montemitro, for their warm hospitality and for sharing their knowledge with the authors, who collected the data in the field (AdT and AP). We would also like to thank to Prof. Marijana Zovko- Končić for helping in the literature search. This article is dedicated to the unforgettable Dorina Giorgetta, our "key" informant in Mundimitar, who unexpectedly passed away, while we were analysing the findings of the field work.

\section{Author details}

${ }^{1}$ University of Gastronomic Sciences, Piazza Vittorio Emanuele 9, I-12060 Pollenzo Cuneo, Italy. ${ }^{2}$ Department of Ecotoxicology, Faculty of Biotechnology, University of Rzeszów, Werynia 502, 36-100 Kolbuszowa, Poland. ${ }^{3}$ Center for the Study of Human Health, Emory University, 550 Asbury Circle, Candler Library 107, Atlanta, GA 30322, USA. ${ }^{4}$ Centre of Ecology and Natural Resources, Faculty of Science, University of Sarajevo, 33-35 Zmaja od Bosne St., 71000 Sarajevo, Bosnia and Herzegovina.

Received: 2 May 2012 Accepted: 24 May 2012

Published: 6 June 2012

\section{References}

1. Leporatti ML, Ivancheva S: Preliminary comparative analysis of medicinal plants used in the traditional medicine of Bulgaria and Italy. J Ethnopharmacol 2003, 87(2-3):123-142.

2. Pieroni A, Quave CL: Traditional pharmacopoeias and medicines among Albanians and Italians in southern Italy: A comparison. J Ethnopharmacol 2005, 101(1-3):258-270. 
3. Pieroni A, Giusti ME, de Pasquale C, Lenzarini C, Censorii E, Gonzales-Tejero MR, Sanchez-Rojas CP, Ramiro-Gutierrez JM, Skoula M, Johnson C, et al: Circum-Mediterranean cultural heritage and medicinal plant uses in traditional animal healthcare: a field survey in eight selected areas within the RUBIA project. J Ethnobiol Ethnomed 2006, 2:16.

4. Gonzalez-Tejero MR, Casares-Porcel M, Sanchez-Rojas CP, Ramiro-Gutierrez JM, Molero-Mesa J, Pieroni A, Giusti ME, Censorii E, de Pasquale C, Della A, et al: Medicinal plants in the Mediterranean area: synthesis of the results of the project Rubia. J Ethnopharmacol 2008, 116(2):341-357.

5. Hadjichambis A, Paraskeva-Hadjichambi D, Della A, Giusti ME, De Pasquale C, Lenzarini C, Censorii E, Gonzales-Tejero MR, Sanchez-Rojas CP, RamiroGutierrez JM, et al: Wild and semi-domesticated food plant consumption in seven circum-Mediterranean areas. Int J Food Sci Nutr 2008, 59(5):383-414

6. Leporatti ML, Ghedira K: Comparative analysis of medicinal plants used in traditional medicine in Italy and Tunisia. J Ethnobiol Ethnomed 2009 $5: 31$.

7. Soukand R, Kalle R: Change in medical plant use in Estonian ethnomedicine: a historical comparison between 1888 and 1994. J Ethnopharmacol 2011, 135(2):251-260.

8. Łuczaj $Ł$ : Changes in the utilization of wild green vegetables in Poland since the 19th century: a comparison of four ethnobotanical surveys. J Ethnopharmacol 2010, 128(2):395-404

9. Pieroni A, Muenz H, Akbulut M, Başer KHC, Durmuşkahya C: Traditional phytotherapy and trans-cultural pharmacy among Turkish migrants living in Cologne, Germany. J Ethnopharmacol 2005, 102(1):69-88.

10. Pieroni A, Houlihan L, Ansari N, Hussain B, Aslam S: Medicinal perceptions of vegetables traditionally consumed by South-Asian migrants living in Bradford, Northern England. J Ethnopharmacol 2007, 113(1):100-110.

11. Sandhu DS, Heinrich M: The use of health foods, spices and other botanicals in the sikh community in London. Phytother Res 2005, 19(7):633-642

12. Yöney A, Prieto JM, Lardos A, Heinrich M: Ethnopharmacy of Turkishspeaking cypriots in greater London. Phytother Res 2010, 24(5):731-740.

13. Ceuterick M, Vandebroek I, Torry B, Pieroni A: Cross-cultural adaptation in urban ethnobotany: The Colombian folk pharmacopoeia in London. J Ethnopharmacol 2008, 120(3):342-359.

14. Pieroni A, Sheikh QZ, Ali W, Torry B: Traditional medicines used by Pakistani migrants from Mirpur living in Bradford, Northern England. Complement Ther Med 2008, 16(2):81-86.

15. Ceuterick M, Vandebroek I, Pieroni A: Resilience of Andean urban ethnobotanies: a comparison of medicinal plant use among Bolivian and Peruvian migrants in the United Kingdom and in their countries of origin. J Ethnopharmacol 2011, 136(1):27-54

16. van Andel T, Westers $P$ : Why Surinamese migrants in the Netherlands continue to use medicinal herbs from their home country. J Ethnopharmacol 2010, 127(3):694-701.

17. Pieroni A, Gray C: Herbal and food folk medicines of the Russlanddeutschen living in Künzelsau/Taläcker, South-Western Germany. Phytother Res 2008, 22(7):889-901.

18. Pieroni A, Giusti ME: Alpine ethnobotany in Italy: Traditional knowledge of gastronomic and medicinal plants among the Occitans of the upper Varaita valley, Piedmont. J Ethnobiol Ethnomed 2009, 5:32.

19. Caramiello Lomagno R, Rovera L, Lomagno PA, Piervittori R: La fitoterapia popolare nella Valle Maira. Annali della Facoltà di Scienze Agrarie dell'Università degli Studi di Torino 1982, XII:217-275.

20. Lomagno P, Lomagno Caramiello R: La fitoterapia popolare nella Valle di Susa. Allionia 1970, 16:165-174.

21. Caramiello Lomagno R, Piervittori R, Lomagno PA, Rolando C: Fitoterapia popolare nelle valli Chisone e Germanasca. Nota prima: Valle Germanasca e bassa Val Chisone. Annali della Facoltà di Scienze Agrarie dell'Università degli Studi di Torino 1984, XIII:259-298.

22. Pons G: Primo contributo alla flora popolare valdese. Bollettino della Società Botanica Italiana 1900, 101-108:216-222.

23. Musset D, Dore D: La mauve et l'erba bianca. Une introduction aux enquêtes ethnobotaniques suivie de l'inventaire des plantes utiles dans la vallée de la Stura. Un'introduzione alle indagini etnobotaniche seguita dallinventario delle piante utili nella Valle della Stura. Mane, France: Musée départemental ethnologique de Haute-Provence, Salagon; 2006.

24. Chimenti Signorini R, Fumagalli M: Indagine etnofarmacobotanica nella Valtournanche (Valle d'Aosta). Webbia 1983, 37(1):69-94.
25. Denarier N: Venti erbe per stare bene. Piante medicinali della Valle d'Aosta. Gressan, Aosta, Italy: Edizioni Vida; 2006.

26. Lomagno P, Lomagno Caramiello R: La fitoterapia popolare della Valle del Sangone. Bollettino SIFO 1977, 23:445-452.

27. Chiovenda-Bensi C: Piante medicinali nell'uso tradizionale della Valle d'Ossola. Atti dell'Accademia Ligure di Scienze e Lettere 1955, 11:32-52.

28. Chiovenda-Bensi C: Tradizioni e usi fitoterapici popolari. La Valsesia. Atti dell'Accademia Ligure di Scienze e Lettere 1957, 13:190-205.

29. Remogna M: Metodi tradizionali di cura a Rimella. De Valle Sicida 1993, 4:221-238.

30. Scarpa A, Steiger L, Donini D, Holznecht H, Poppi C: Etnomedicina comparata delle etnie ladine. Studi etno-antropologici e sociologici 1988, 16:37-64.

31. Poppi C: Medicina popolare in Val di Fassa: relazione di ricerca sul campo. Mondo Ladino 1989, XIII(3-4):287-326.

32. Scarpa A: Altri risultanze sulla medicina popolare in Val di Fassa. Mondo Ladino 1990, 3-4:257-270.

33. Barbini S, Tarascio M, Sacchetti G, Bruni A: Studio preliminare sulla etnofarmacologia delle comunità ladine dolomitiche. Informatore Botanico Italiano 1999, 31(1-3):181-182.

34. Cappelletti EM, Trevisan R, Folletto A, Cattolica PM: Le pinate utilizzate in medicina popolare in due vallate trentine: Val di Ledro e Val dei Mocheni. Studi Trentini di Scienze Naturali 1981, 58:119-140.

35. Zampiva F: Le principali erbe della famacopea cimbra. Cimbri-Tzimbar Vita e cultura delle comunità cimbre 1998, X(19):135-146.

36. Zampiva F: Róasan (Flora cimbra). I nomi dimenticati di erbe piante e fiori. Verona, Italy: Edizioni Curatorium Cimbricum Veronense; 2000.

37. Pieroni A, Giusti ME, Münz H, Lenzarini C, Turković G, Turković A Ethnobotanical knowledge of the Istro-Romanians of Žejane in Croatia. Fitoterapia 2003, 74(7-8):710-719.

38. Pieroni A, Nebel S, Quave C, Munz H, Heinrich M: Ethnopharmacology of liakra: traditional weedy vegetables of the Arbereshe of the Vulture area in southern Italy. J Ethnopharmacol 2002, 81(2):165-185.

39. Pieroni A, Quave C, Nebel S, Heinrich M: Ethnopharmacy of the ethnic Albanians (Arbereshe) of northern Basilicata, Italy. Fitoterapia 2002, 73(3):217-241.

40. Quave $\mathrm{CL}$, Pieroni A: Folk illness and healing in Arbëreshë Albanian and Italian communities of Lucania, Southern Italy. J Folklore Res 2005, 42:57-97.

41. Nebel S, Pieroni A, Heinrich M: Ta chorta: wild edible greens used in the Graecanic area in Calabria, Southern Italy. Appetite 2006, 47(3):333-342

42. Nebel $S$, Heinrich M: Ta chòrta: A comparative ethnobotanical-linguistic study of wild food plants in a graecanic area in Calabria, Southern Italy. Econ Bot 2009, 63(1):78-92.

43. Maxia A, Lancioni MC, Balia AN, Alborghetti R, Pieroni A, Loi MC: Medical ethnobotany of the Tabarkins, a Northern Italian (Ligurian) minority in south-western Sardinia. Genet Resour Crop Ev 2008, 55(6):911-924.

44. Rešetar M: Die serbokroatischen Kolonien Süditaliens. Wien: Alfred Hölder; 1911

45. AISEA: Codice Deontologico. http://www.aisea.it/codice.asp.

46. Pignatti S: Flora d'Italia. Bologna, Italy: Edagricole; 1997.

47. Committee TFEE: Flora Europaea on CD-ROM. Cambridge, UK: Cambridge University Press; 2001.

48. Šugar I: Hrvatski biljni imenoslov. Nomenclator botanicus Croaticus. Zagreb, Croatia: Matica Hrvatska; 2008.

49. Penzig O: Flora popolare italiana. Raccolta dei nomi dialettali delle principali piante indigene e coltivate in Italia. Genoa, Italy: Orto Botanico della Regia Università; 1924

50. Manzi A: Le piante alimentari in Abruzzo. La flora spontanea dell'alimentazione umana. Chieti, Italy: Tinari; 1999.

51. Guarrera PM: Usi e tradizioni della flora italiana. Medicina popolare ed etnobotanica. Rome, Italy: Aracne; 2006.

52. Guarrera P, Lucchese F, Medori S: Ethnophytotherapeutical research in the high Molise region (Central-Southern Italy). J Ethnobiol Ethnomed 2008 4.7

53. Motti $R$, Antignani $V$, Idolo M: Traditional plant use in the Phlegraean Fields Regional Park (Campania, Southern Italy). Hum Ecol 2009, 37(6):775-782.

54. Menale B, Amato G, Di Prisco C, Muoio R: Traditional uses of plants in North-Western Molise (Central Italy). Delpinoa 2006, 48:29-36. 
55. Idolo M, Motti R, Mazzoleni S: Ethnobotanical and phytomedicinal knowledge in a long-history protected area, the Abruzzo, Lazio and Molise National Park (Italian Apennines). J Ethnopharmacol 2010, 127(2):379-395.

56. Bakić J, Popović M: Nekonvencionalni izvori u ishrani na otocima i priobalju u toku NOR-a. Izd Mornaričkog glasnika 1983, 49-55.

57. Grlić L: Enciklopedija samoniklog jestivog bilja. Rijeka, Croatia: Ex Libris; 2005.

58. Curčić V: Narodne ribarstvo u Bosni i Hercegovini. Part 2. Glasnik Zemaljskog Muzeja u Bosni i Hercegovini 1913, 25:421-514.

59. Sardelić S: Samoniklo jestivo bilje - mišanca, gruda, parapač. Etnološka istraživanja 2008, 1(12/13):387-396.

60. Istrianet.org: Fritade - Fritaje - Omelets. Ostaria Istriana. http://www. istrianet.org/istria/gastronomy/osteria/fritade.htm.

61. Tomei PE, Lippi A, Uncini Manganelli RE: L'uso delle specie vegetali spontanee nella preparazione delle zuppe di magro in Lucchesia (LU). In Funghi, tartufi ed erbe mangerecce: 1995; L'Aquila, Italy; 1995:243-248.

62. Camangi F, Stefani A: Le tradizioni phytoalimurgiche in Toscana: le piante selvatiche nella preparazione delle zuppe. Rivista di Preistoria, Etnografia e Storia naturale, Istituto Storico Lucchese 2004, 2(1):7-17.

doi:10.1186/1746-4269-8-21

Cite this article as: di Tizio et al:: Traditional food and herbal uses of wild plants in the ancient South-Slavic diaspora of Mundimitar/ Montemitro (Southern Italy). Journal of Ethnobiology and Ethnomedicine 2012 8:21.

\section{Submit your next manuscript to BioMed Central and take full advantage of:}

- Convenient online submission

- Thorough peer review

- No space constraints or color figure charges

- Immediate publication on acceptance

- Inclusion in PubMed, CAS, Scopus and Google Scholar

- Research which is freely available for redistribution 